\title{
Fukushima: Towards a reconsideration of China's nuclear plans?
}

\section{Marie-Hélène Schwoob}

\section{(2) OpenEdition \\ 1 Journals}

Electronic version

URL: http://journals.openedition.org/chinaperspectives/5574

DOI: 10.4000/chinaperspectives.5574

ISSN: 1996-4617

Publisher

Centre d'étude français sur la Chine contemporaine

\section{Printed version}

Date of publication: 30 July 2011

Number of pages: 64-65

ISSN: 2070-3449

\section{Electronic reference}

Marie-Hélène Schwoob, « Fukushima: Towards a reconsideration of China's nuclear plans? », China Perspectives [Online], 2011/2 | 2011, Online since 30 June 2014, connection on 15 September 2020 URL : http://journals.openedition.org/chinaperspectives/5574 


\section{Fukushima:}

\section{Towards a reconsideration of China's nuclear plans?}

Analysis by Marie-Hélène Schwoob based on:

- Wang Jiabo, "Views on the Fukushima crisis," Guangming Ribao, 26 March 2011.

- Deng Li, "Modernisation of crisis handling: Inspecting the national nuclear system," 21 Shiji lingji Baodao (21st Century Business Herald), 25 March 2011.

- Zhao Yongxin, Jiang Jianke, and Zhang Yujie, "Three questions for China's nuclear plans," Renmin Ribao (People's Daily), 11 April 2011.

! $t$ is striking to see the extent to which articles that preceded the Fukushima crisis had unanimously considered nuclear power an inseparable part of China's energy strategy. Apart from the 13 plants in operation, nearly 30 are under construction and 90 more are planned. This strategy of accelerated nuclear development is aimed at ensuring that 15 percent of China's energy will come from non-coal sources by 2020, without disturbing the overall national power supply. After the accident in Japan, questions have arisen in China over possible reconsideration of the plans set for the nuclear energy sector.

Following the catastrophe in Japan, the Chinese government speedily ordered a halt to the examination and approval of new nuclear projects. In Wang Jiabo's view, this decision to put the programmes on hold and begin a review of nuclear security was something the entire international community felt compelled to adopt. According to Wang, this action required all the more courage and determination in China, as the government was in the midst of urgently adopting low-carbon-emitting energy strategies.

Expert consultations and inspections of nuclear installations in Chinese provinces following Fukushima helped formulate a general evaluation of management systems and nuclear safety in China. In their articles, various authors reported the views of experts and evaluators affirming a high level of nuclear safety in China. Zhao Yongxin, Jiang Jianke, and Zhang Yujie hold that nuclear technologies used in China are of an advanced nature, corresponding to international standards. Further, they point to the rigour of the Chinese supervision system, observing that China drew lessons from the Chernobyl disaster and adopted surveillance systems that follow standards set by the International Atomic Energy Agency. Deng Li says that surveillance procedures for measuring radioactivity as well as for evaluating the plants and their risk levels were reinforced following Fukushima.

The authors rely largely on an analysis of China's emergency preparedness. Procedures for handling nuclear accidents consist of three levels of response: the state, local governments, and enterprises:

- Within the State Council, 20 units of related ministries and administrations form a coordination committee for emergency procedures in case of a nuclear accident. These units are responsible for setting up and adopting crisis-handing measures, as well as personnel training and the direction of exercises relative to emergency situations;

- At the provincial level, the mechanisms include emergency intervention organs and rescue teams capable of acting in terms of measuring levels of radioactivity, protection from radiation, decontamination procedures, medical treatment, etc.;

- At the plant level, the measures include detailed regulations on procedures to be followed in case of an incident, as well as teams geared for emergency interventions.

Deng Li's analysis of Zhejiang Province's case describes a network of military authorities, groups of local experts, and government officials - each armed with an emergency mechanism to deal with nuclear accidents - as well as materials such as reserves of iodine or perhaps decontamination vehicles. Nevertheless, according to Zhan Chen, director of the environmental protection bureau in Zhejiang Province, emergency procedures need further improvement. Zhan points to the lack of technical experts and the need to train crisis management teams. Further, inter-province coordination needs to be improved, as well as coordination among systems for prior warning, meteorology, seismology, and oceanography.

Despite the questions raised by the Fukushima accident, renouncing nuclear energy is clearly not in the cards for China. Zhao, Jiang, and Zhang say that in a context of worldwide energy shortage and global warming, nuclear energy is an ineluctable strategic choice for China. They consider nuclear energy development imperative for economic development and improving people's living standards. According to the authors of the People's Daily article, nuclear power enjoys advantages that place it above other energy sources: It is an affordable and efficient means of producing electricity. It is also viable, given the maturity of technologies used. Compared with wind, solar, and other new sources, nuclear energy has another advantage that cannot be ignored: it can supply stable power of great quantity and quality, making it indispensable for the scale of China's needs. As for carbon emissions, nuclear plants win hands down compared with traditional energy sources. In this context, People's Daily notes the targets set in the $12^{\text {th }}$ Five-Year Plan for greater attention to energy needs and environmental protection: reducing carbon dioxide emissions by 17 percent by 2015 compared with 2010, reducing sulphur dioxide by 8 percent; increasing the use of non-fossil fuels in energy production from 8.3 percent in 2010 to 11.4 percent in 2015 , etc. The authors say that without nuclear energy, it would be impossible to attain these targets.

Alongside grand national orientations positioning nuclear power as a pillar of China's energy strategy, local governments and energy companies have likewise shown unbridled enthusiasm for nuclear production. Deng Li 
considers the question of whether such zeal for this energy source on the part of local authorities is not exaggerated. These authorities have demonstrated a real desire to be at the cutting edge of China's nuclear programme (核电站的选址 “打破头” - hedianzhan de xuanzhi dapotou). It is also a major strategy given the objective of reducing energy intensity that has been imposed on them. Nuclear energy development has thus emerged as a major bulwark of the strategy for reducing energy consumption in provinces or municipalities such as Chongqing. Nuclear energy development plans represent an assurance of energy supply for local governments, but they also constitute a source of considerable revenue, jobs, and GDP growth... Local enterprises see in nuclear energy programmes an opportunity to invest billions of yuan and to be assured of stable revenue yield (compared with renewable energy). Deng Li concludes that the level of interest shown by Chinese provinces for nuclear programmes is therefore hardly surprising.

The latest nuclear energy development programme ${ }^{(1)}$ set production capacity at 40 billion $\mathrm{GW}$ in 2020. Going by estimates of projects already underway, China's nuclear capacity will have surpassed that target by 2020. Discussions in the National People's Congress preceding the $12^{\text {th }}$ Plan's publication had spoken of doubling the capacity to $80 \mathrm{GW}$ in 2020.

Some of the 90 new plants currently in the pipeline are close to drinking water sources, and experts have raised doubts over the degree of risk for localities. Li Ganjie, director of the department of nuclear safety, warns that a number of enterprises and local governments have shown too much enthusiasm for nuclear energy: "The targets set are overambitious, and actions taken have been too hasty and lack realism or expertise, thus raising risks not only over safety but also over economic viability."

Li Ganjie says the greatest challenge faced by China's nuclear programme is a lack of competent human resources in the technological domain. The speed and scale at which China's nuclear projects have developed could well lead to a dilution and disorganisation of technically competent personnel. This could have consequences not only for the projects currently underway but also for future plants. Furthermore, a lack of competent technicians could hurt China badly in the event of a nuclear accident, as would a dispersal of crisis management machinery among multiple ill-coordinated entities.

Despite these risks and drawbacks, the authors agree that in respect of nuclear energy development, China has simply no choice. The People's Daily authors conclude that "China's nuclear programme won't stop gorging itself for fear of choking" (在发展核电问题上, 不应因嘻废食 - zai fazhan hedian wenti shang, buying yinyefeishi).

\section{Translated by N. Jayaram}

